\title{
Maqasid Ash-Shari'ah Framework and the Development of Islamic Finance Products: The Case of Indonesia
}

\begin{abstract}
Abdul Qoyum ${ }^{1}$
Abstact. The objective of this research is to discuss the concept of Maqasid Ash-Shari'ah as well as to propose new concept of Maqasid Ash-Shari'ah framemork that will give many benefit in Islamic financial product development. Using a qualitative approach and using literature review, this study concludes that, the purpose of sharia can be in the form of micro and macro as well. Both of these goals must be able to be realized by Islamic finance, primarily through its products. In order to realize these two objectives, the process of the development of Islamic financial products is not only the concern of the sharia council, but also involving microprudential and macropruedential authorities. Therefore, here, the process of establishing Islamic financial products may involve Bank Indonesia, OJK, LPS, as well as DSN. The big goal is that every product can actually generate maslahah, both at micro and macro levels.

Keywords: Maqasid Ash-Shari'ah Framework, Islamic Finance Product, Micro-Maqasid, Macro-Maqasid.

Abstrak. Tujuan dari penelitian ini adalah untuk membahas konsep Maqasid Ash-Shari'ah serta mengusulkan konsep baru berupa framemork Maqasid Ash-Shari'ah yang akan memberikan banyak manfaat dalam pengembangan produk keuangan Islam. Menggunakan pendekatan kualitatif dan menggunakan tinjauan pustaka, penelitian ini menyimpulkan bahwa, tujuan syariah bisa dalam bentuk mikro dan makro. Kedua tujuan ini harus dapat diwujudkan oleh keuangan Islam, terutama melalui produknya. Untuk mewujudkan dua tujuan ini, proses pengembangan produk keuangan Islam tidak hanya menjadi perhatian dewan syariah, tetapi juga melibatkan otoritas mikroprudensial dan makroprekuensi. Oleh karena itu, di sini, proses pembentukan produk keuangan Islam dapat melibatkan Bank Indonesia, OJK, LPS, serta DSN. Tujuan utamanya adalah setiap produk benar-benar dapat menghasilkan maslahat, baik di tingkat mikro maupun makro.
\end{abstract}

Kata kunci: Kerangka Maqasid Ash-Shari'ah, produk keuangan Islam, Maqasid-mikro, Maqasid-makro

\footnotetext{
${ }^{1}$ Faculty of Islamic Economics and Business, UIN Sunan Kalijaga | qoyum13@gmail.com
} 


\section{Introduction}

Islamic finance has been undergoing a tremendous development over the last decades not only in moslem countries but also in non-moslem countries. The current development of Islamic finance has been strengthened by the creation of various supports and infrastructures in Islamic finance (Dusuki, 2009). This can be seen from the recent progress in which Islamic finance products have been flourishing and gaining wider acceptance in various areas, to name a few, such as Islamic hedging (tahawwuth al-Islami) which previously was considered as prohibited product, now is being accepted as sharia compliant product to cater the risk management purposes. Not surprisingly, this product is then being accepted by National Sharia Board (Dewan Syariah Nasional). Aside from that, there are many other Islamic finance products that were previously deemed as unlawful instruments, now is being accepted by Islamic scholars.

In figh muamalah, the design and development of Islamic finance products must be based on prudential principle, in which that products should comply with sharia principles. Islamic finance literature proclaims that Islamic financial system differs enormously than that of conventional financial system in many ways. The striking difference between the two financial systems can be seen from the values which guide the whole operation and outlook of financial system (Dusuki, 2009). In Islamic finance, these values are reflected from the Maqasid Ash-Shari'ah or the objectives of sharia with ultimate aim to promote human wellbeing (Asutay, 2012). Therefore, by applying strictly some general standards in Maqasid Ash-Shari'ah, the problem of convergence in Islamic finance towards existing neo-classical system could be overcome gradually. In addition, mimicking of conventional finance that has been practiced in Islamic financial industry (Asutay and Harningtyas, 2015), in which the products are very concern in fulfilling 'form' rather than 'substance' (or social function), can be reduced. 
Bringing in the issue of legal maxim in Islamic finance, the renowned legal maxim of "any form of muamalah is allowed unless there is a prohibited proof" brings a tremendous impact in the design of Islamic finance products. The restricted view of understanding this maxim allows sharia scholars only focusing on the legal forms of a contract rather than the substance. Whereas, the 'substance' of the sharia has crucial implications for the realization of Maqasid Ash-Shari'ah that equally important in structuring a sharia compliant product (Dusuki and Abozaid, 2007). In this regard, Maqasid Ash-Shari'ah shoud come to the forefront in the development of Islamic finance product.

Understanding Maqasid Ash-Shari'ah (the objectives of sharia) is crucially important in all aspects of our life. Without having a solid understanding of this Maqasid, no one can get the wisdom and benefits (Hurayra, 2015). According to Monzur-E-Elahi (2012), Maqasid Ash-Shari'ah plays an important role in enhancing the Ummah's abilities and qualities of intellectual reform and civilization renewal. In the context of Islamic finance, Maqasid Ash-Shari'ah is not only focus on the prohibition of riba, but also to promote the circulation of wealth within society, the continuity of wealth investment and disbursement, achieving the economic prosperity for the whole society by satisfying their basic needs, transparency in financial activities, and permissibility of private and public ownership of the wealth (Hurayra, 2015). Hence, based on the aforementioned explanation, the application of Maqasid Ash-Shari'ah in developing of Islamic finance product is very crucial.

There are various studies on the topic of Maqasid Ash-Shari'ah in Islamic finance literature either in qualitative or quantitative research. In qualitative research, Dusuki and Abozaid (2007) mentioned that the challenges faced in Islamic finance with regard to its relationship with Maqasid Ash-Shari'ah, namely; (i) the proper understanding of Maqasid Ash-Shari'ah in Islamic economics, (ii) the methods of implementing Maqasid Ash-Shari'ah in Islamic banking and finance, (iii) the potential conflicts between macro Maqasid and micro Maqasid, and (iv) the possible abuse of Maqasid Ash-Shari'ah to justify 
certain financial contracts which contradict with the sharia texts. Meanwhile, the research conducted by Laldin and Furqani (2013) documented three specific ends (Maqasid) in Islamic finance, namely: (i) wealth circulation, (ii) fair and transparent financial practices, and (iii) justice at the micro and macro-level. To achieve those ends, the sharia provides means (wasa'il) such as facilitating financial contracts, establishing values and standards and instituting social responsibility.

The recent work by Hurayra (2015) found that the bank has been achieving the main and upmost (macro) Maqasid Ash-Shari'ah of public interest and the prohibition of riba over the last two decades. However, the minor Maqasid Ash-Shari'ah such as freeing from any kinds of debt and other benefits that related to macroeconomics factors is yet to be achieved. Antonio et al. (2012) developed Maqasid Index approach using SAW (Simple Additive Weighting) method and concluded that Islamic banks in Indonesia show better performance than that of Islamic banks in Jordan (Antonio et al., 2012). Another research by Asutay and Harningtyas (2015) indicated that there is lack of achievement in Maqasid Ash-Shari'ah performance of Islamic bank and finance. In the same token, Yazid et al. (2015) documented the importance of fairness, transparency and Maqasid Ash-Shari'ah in Islamic finance. Unfortunately, some Islamic banks did not uphold these values in their products and operations.

Although several studies have investigated the issues of and Maqasid Ash-Shari'ah, however to the limited knowledge of the author, there is less discussion on the Maqasid Ash-Shari'ah framework in Islamic finance. Therefore, the objective of this research is aimed to discuss the Maqasid framework in developing Islamic financial products. Besides, this research focus is to design the framework of Maqasid and its application on Islamic finance products.

The rest of the paper organized as follows: in section II, we provide the literature review on Maqasid Ash-Shari'ah. Part III outlines the basic role of Maqasid Ash-Shari'ah in Islamic finance. Section IV discuss the details of Maqasid 
Ash-Shari'ah Framework in Islamic finance products, and finally we conclude in section $\mathrm{V}$ with the conclusion of main findings.

\section{Literature Review}

Maqasid Ash-Shari'ah is the most important element of current Islamic finance practice. Hence, it is evidently as an integral aspect of sharia and the key point of Shariah Supervisory Board of Islamic financial institutions (Antonio and Sanrego, 2012). According to Ibn Qayyim al-Jawziyyah (d. 1356), the objective of sharia is for safeguarding people's interest in this world and the Hereafter (Ibn Qayyim, n.d.). Regarding the concept of Maqasid AshShari'ah, al-Ghazali said:

"The objective of the sharia is to promote the welfare of human beings, which lies in safeguarding their faith, their life, their intellect, their posterity, and their wealth. Whatever ensures the safeguard of these five fundamentals serves public interest and is desirable" (Al-Ghazali, 1356/1937; see also Chapra, 1998; Chapra, 2008).

Al-Shatibi approves al-Ghazali's list and sequence, hereby indicating that they are the most preferable in terms of their harmony with essence of sharia (Ibn Ashur, 2006).

In addition, Dusuki and Abozaid (2007) definee Maqasid Ash-Shari'ah as the main objectives and the rationale of the sharia. A comprehensive and careful examination of the sharia rulings entails an understanding that sharia aims at protecting and preserving public interest (maslahah) in all aspects and segments of life. Maqasid Ash-Shari'ah explain the 'wisdoms behind rulings,' such as 'enhancing social cohesion,' which is one of the wisdoms behind charity, being good to one's neighbors, and greeting people with peace. Wisdoms behind rulings also include 'developing consciousness of God,' which is one of the rationales behind regular prayers, fasting, and supplications. In depth comprehension of the objectives of sharia is important for analogical deduction and other human reasoning and its methodology (Kamali, 1999). 
Maslahah is one of the juristic devices that have always been used in Islamic legal theory to promote public benefit and prevent social evils or corruption. The plural of the Arabic word maslahah is masallih which means welfare, interest or benefit. Literally, maslahah is defined as seeking the benefit and repelling harm. What moslem jurists mean by maslahah is the seeking of benefit and the repelling of harm as directed by the Lawgiver (Dusuki and Abozaid, 2007). Maslahah, considering its benefits, are aimed to shape the human needs, hence is such a tool which allows creativity, dynamism and flexibility in terms of social policies (Al-Mubaarak and Osmani, n.d.).

There are 3 types of maslahah namely; maslahah al-mu'tabarah, maslahah almulghah, and maslahah al-mursalah. Al-maslahah al-mu'tabarah or benefits acknowledged by the sharia are those which are vividly expressed in the sharia texts, and approved its benefits. As examples, the commandment for Jihad, in which is aimed to safeguard the Deen ${ }^{1}$. On the other hand, al-masalih al-mulghat or the benefits which are rejected are also clearly mentioned in the texts, and that are disapproved in the sharia. For example, transactions with riba (interest, sometimes also used for 'usury') are also prohibited ${ }^{2}$ despite the fact that riba enables one to make profit. The point of discussion here, al-masalih al-mursalah, is benefits which are neither mentioned explicitly in favour, nor denied outright in the textual scriptures. Khallaf (1990) mentioned it as "The benefits which the lawgiver did not impose as a rule to be implemented, and neither there is any textual indication acknowledging it nor rejecting it."

Although the sharia accepts benefits, however does not accept all that leads to a benefit. There are some condition on how the benefit can be accepted by sharia, namely (Al-Ashqar, 2004): Not contradict with an established hukm. There can be no maslaha to create a new ibadah, or to add any rukn or shart of any established ibadah, or to eliminate some parts of any ibadah. Maslahah should be based on a qat'ee (definitive) references, and not zanni (speculative).

\footnotetext{
${ }^{1}$ The benefit of qisas has been explicitly mentioned in the Qur'an; in Surah al-Baqarah [2]: 179.
}

2 Al-Qur'an, Surah al-Baqarah [2]: 275. 
When a hukm is enacted, the maslahah of that hukm should be greater than the mafsadah of it, neither equal nor less. The maslahah should be a general (كلّية) and inclusive maslahah, not limited and specific (خاّصة) to some individual or group. The maslahah should be compatible with the sharia standards of maslahah, and reasonably understood.

All sharias' teachings, injunctions and prohibitions are related to the grand wisdom (hikmah) of securing human interests in the worldly life and the hereafter. All sharia rules that contain obligations and duties bring benefit and prosperity, and all its prohibitions prevent human from harm and hardship (Al Baqarah [2]: 30; Ali Imran [3]: 191; Al An'am [6]: 165; Sad [38]: 27; Ad Dukhan [44]: 38-39; Al Mulk [67]: 1-2) (Laldin and Furqoni, 2013). The Qur'an is expressive of this when it mentions the most important purpose of the Prophethood of Muhammad (peace be upon him) in such terms as: "We have not sent you but a mercy to the world" (Al Anbiya [21]: 107). This can also be seen in the Qur'an's characterization of itself in that it is "a healing to the (spiritual) ailment of the hearts, guidance and mercy for the believers" (Yunus [10]: 57) Another example, when Qur'an prescribes qasas (retaliation), it speaks of the rationale of it, that applying retaliation prevents further killing "There is life for you in qasas" (Al Baqarah [2]: 179). Similarly, when Quran prohibits wine it says that wine is the works of devil as it causes quarrel and instills hatred and enmity among moslems "The devil only wants to excite enmity and hatred between you in intoxicants and gambling and hinder you from remembrance of Allah and from prayer" (Al An'am [6]: 91).

Maqasid Ash-Shari'ah is very important to be attained in Islamic finance because of several reasons. First, there is a strong relationship between the objectives of Maqasid Ash-Shari'ah and the objectives of business transactions, as can be observed from the position of the wealth within Islamic law and Maqasid Ash-Shari'ah that requests the preservation of wealth in everyday business activities and the promotion of socially responsible activities. As a result, if the objectives of Maqasid Ash-Shari'ah in business transactions are 
neglected, it may result in poverty and anarchy. Second, the business transactions in domestic and international trade should be based on the principles of Islamic law, and the fundamental objectives of Maqasid AshShari'ah in finance and business shall be applied as core guidelines to implement all types of financial transactions. Third, the particular objectives of Maqasid Ash-Shari'ah in business transactions must have perpetuity and constant outlook of the universal objectives of Maqasid Ash-Shari'ah. Last but not the least, the regulations of business transactions should be within the rules and the requirements of Maqasid Ash-Shari'ah and Islamic law. In other words, Maqasid Ash-Shari'ah must administer and regulate the sharia principle of the Islamic finance (Lachsasna and Sulaiman, 2010).

In addition, in the context of product development in Islamic finance, Maqasid Ash-Shari'ah must be used as basic guideline in designing it. The main objective is, the product which is issued fully reflect the public benefit (maslahah). Hence, the bringing of word 'Islam' in finance means the economy is more developed and enhanced and consequently it establishes justice and protects pubic rights. Laldin and Furqoni (2013) state there are End (Maqasid) and Means (Wasilah). According to them, the end of Maqasid is; wealth circulation; fair and transparent financial practices; and justice in the macro and micro-dimension. Whereas, the means (wasilah) of Maqasid is the way in which the end (Maqasid) can be realized. In their view, there are some element in this regard namely; facilitating financial contracts; Establishing values and standards; and instituting social responsibility (Laldin and Furqoni, 2013).

Dusuki and Abozaid (2007) stated the differentiation between validity versus permissibility in sharia compliance product. The first question that needs to be raised is what should be the basis in justifying whether a product is sharia compliant or not? In other words, what are the approaches in fiqh when determining whether a contract is valid and permissible from sharia perspectives? Schools of figh differed on the issue of determining the basis of contract validity (sahih). Some emphasizes on its legal form while others stress 
on its substance and the intention of contracting parties. These differences can be attributed to the sharia texts as there are some who based their opinion on a hadith that "matters are determined by intention". Based on this Hadith, validity of all contracts must be determined by niyyah (intention), i.e. the purpose or substance of the contract, not by just looking at its form or structure alone. However, some scholars like Imam Shafi i found it is impractical to determine the validity of contracts by means of intention, as it is difficult and sometimes impossible to identify the intention of the contractors. Moreover, they found some sharia texts suggesting that judging things must be based on their form and appearance.

To reconcile between these two conflicting texts in a practical way, scholars distinguished between two types of hukm (ruling): hukm qada'i and hukm diyani. The former concerns with contract that complies with all sharia conditions and requirements pertaining to a contract in its form and structure. The later concerns with compliance of the substance or contract purpose which must be in line with the sharia. If the contract structure is sharia compliant, then it could be termed as a valid contract (sahih qadaan). On the other hand if all the contractors' purposes i.e. the substance of the contract is sharia compliant, then it is termed as permissible (valid diyanatan). Thus, a transaction is deemed to be sahih qadaan when it serves the legal purpose and intention, and sahih diyanatan if the contract meets all contractual conditions and requirements. Consequently, a sahih (valid) contract is not necessarily halal (permissible) (Dusuki and Abozaid, 2007).

In term of current of Islamic finance product, according to Habib Ahmed (2011), the following are the three types of products which can be identified: Pseudo-Islamic Product: Pseudo-Islamic finance products are chracterized by its onformity with the legal form only, but does not fulfill the substance of the sharia. This will be the case when ruses (hillah) are used to develop products that fulfill the legal form of the contracts, but in substance represent an illegal transaction; Sharia-compliant Products: Sharia-compliant products would satisfy 
the form and substance of Islamic law, but fail to pay attention to the social goals. Specifically, a sharia compliant product will not meet the survival and security financial needs of the poor and small/micro enterprises adequately; Sharia-based Products: A sharia-based product is a sharia-compliant product that fulfills the legitimate needs of all market segments. Specifically, a sharia-based product will not only satisfy the form and substance of Islamic law, it will also satisfy the survival and security needs of all sections of the population including the poor and small/micro entrepreneurs. Thus, a sharia-based product is a sharia-compliant one realizing the social goals. For example, a home financing product that targets all segments of the population, including the poor, would be sharia-based ${ }^{3}$. In other word, we can say this product is as Maqasid-compliant product.

How to ensure that Islamic finance product are Maqasid compliant? He proposes legal requirement whereby the key decision makers is Sharia Supervisory Board. The sharia department and Sharia Supervisory Board (SSB) play a vital role in ensuring the fulfillment of legal requirements. The SSB has direct responsibility to ascertain that the product complies with the principles and values of the sharia before it is launched in the market. In addition, social requirement will be obliged to Board of Director. As pointed out, a bank's social performance can be established by identifying the market segments and needs that its products serve. As market/product decisions are made at the strategic levels, social responsibility of the bank and its implications at the product levels will be established at the highest levels of organizational decision making.

\section{Method}

This paper is qualitative research which is written based on literature of Islamic finance and Maqasid Ash-Shari'ah. The paper will review some literature on Islamic finance and also Maqasid Ash-Shari'ah from both theoretical and

\footnotetext{
${ }^{3}$ Some Islamic scholars say that a sharia based product is an Islamic finance product that is properly used based on the spirit of right aqad and correct Maqasid al-Shari'ah.
} 
empirical research. This paper, then, propose model on how Islamic finance are created based on Maqasid Ash-Shari'ah.

\section{Result and Discussion}

Maqasid Ash-Shari'ah is very essential in Islamic finance, including its product development. Without the fulfillment of Maqasid, Islamic finance will be in chaos and uncertain (Mohammad and Shahwan, 2013). Even, based on the current practice in which many people, particularly, academicians put a very much focus on criticizing the performance of Islamic finance products. Some of them argue that Islamic finance products, currently, cannot attain the Maqasid Ash-Shari'ah . It can be seen from all their products whereby, mimicking product, in which very same with its conventional counterparts, affect to the existence of pseudo-Islamic finance product. It can be understood, sine in majority, the practitioners are just concern on how to design sharia compliant product rather than Maqasid compliant. This condition, based on all facts above is very critical in the view of the trust from the society pertaining to the quality of Islamic finance to solve the problem of society. In the long-run case, it can cause distrust from the moslem community.

Therefore, it is very crucial for Islamic finance stakeholder to discuss the Maqasid Ash-Shari'ah framework, especially on how to develop Islamic finance product. This framework can be used as general guideline pertaining to the product development. Figure 1 below describes the general framework of Islamic finance, whereby the ultimate objective is attainment of maslahah. The maslahah can be achieved if the two Maqasid can be realized, namely macroMaqasid and micro-Maqasid. The macro-Maqasid of Islamic finance product is; First, wealth circulation, this objective is derived from the Qur' anic explanation of the reason behind a rule regarding distribution: ". . . so that wealth is not circulated among the rich in the society only" (Al Hasyr [59]: 7). All product of Islamic finance must be oriented to ensure that financial resource circulate in all society. For example, when DSN discussing product of Islamic Hedging, this actually cannot be say that this product is society's product base, since the users 
of Islamic hedging is Islamic banking per se. Second, fair and transparent financial practices, in which all Islamic finance products have to promote fair and transparent economic activities ${ }^{4}$. The Qur'an has stressed that all agreements and contracts should be as transparent and clear as possible ( $\mathrm{Al}$ Baqarah [2]: 282) (Laldin and Furqoni, 2013).

Third, justice in the macro-dimension and micro-dimensions. At the macro level, the goal is to realize social justice. Islamic finance product which is attempted to realize social justice must be focus on how to circulate of people wealth, efficiency in resource utilization, fulfilling society's basic needs, elimination of poverty and improving human wellbeing. At the micro-level, Islamic finance product must ensure that all pillars and conditions of aqad (contract) have been fulfilled. It means that economic transactions demand equal rights and opportunities and are not allowed to be enforced without the mutual consent of both parties (taradi) and unfair dealings or unjustified actions that lead to economic injustice or exploitation are condemned.

\footnotetext{
${ }^{4}$ Fairness means equity and honesty between the transacting parties as well as efficiency in transactions, while Transparency means that all financial transactions must be conducted in such a manner that all the parties are clear about all important facts of the transactions necessary for the avoidance of disputes, clashes or damages to any party.
} 
TIFBR | Tazkia Islamic Finance and Business Review

Volume 12(2), 2018

\section{MASLAHAH}
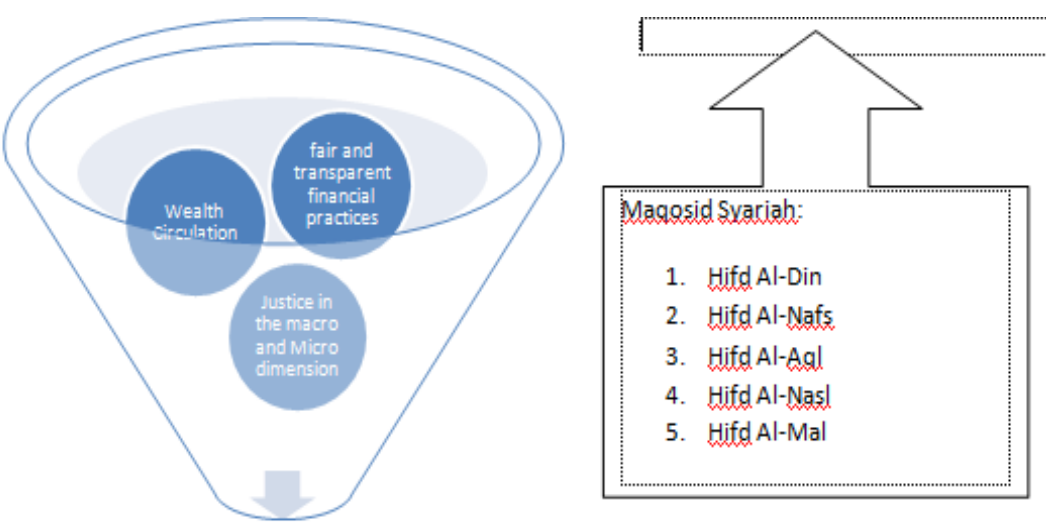

Wasilah (Means)

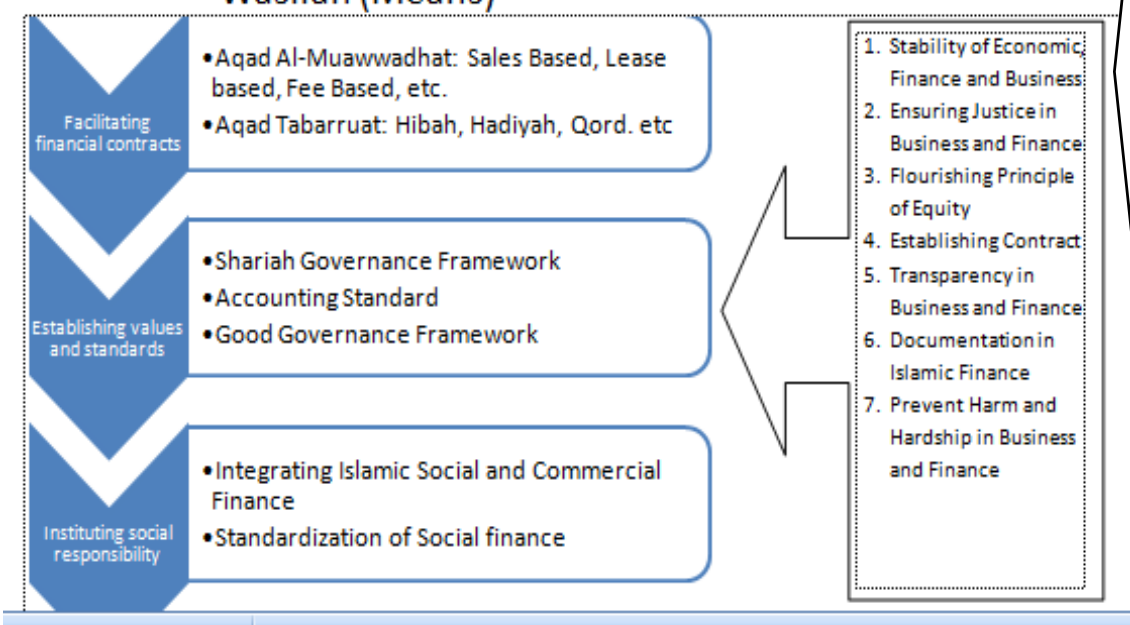

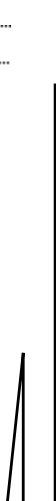

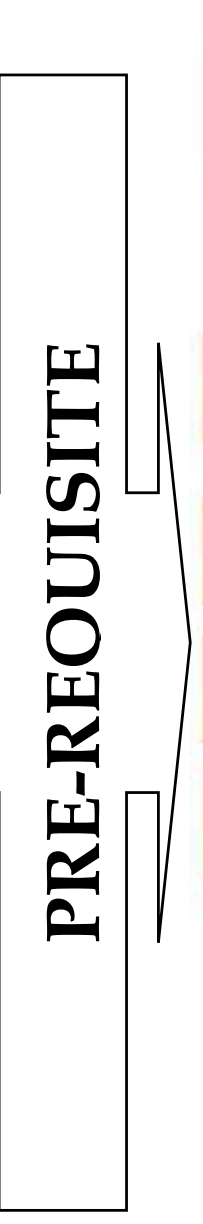

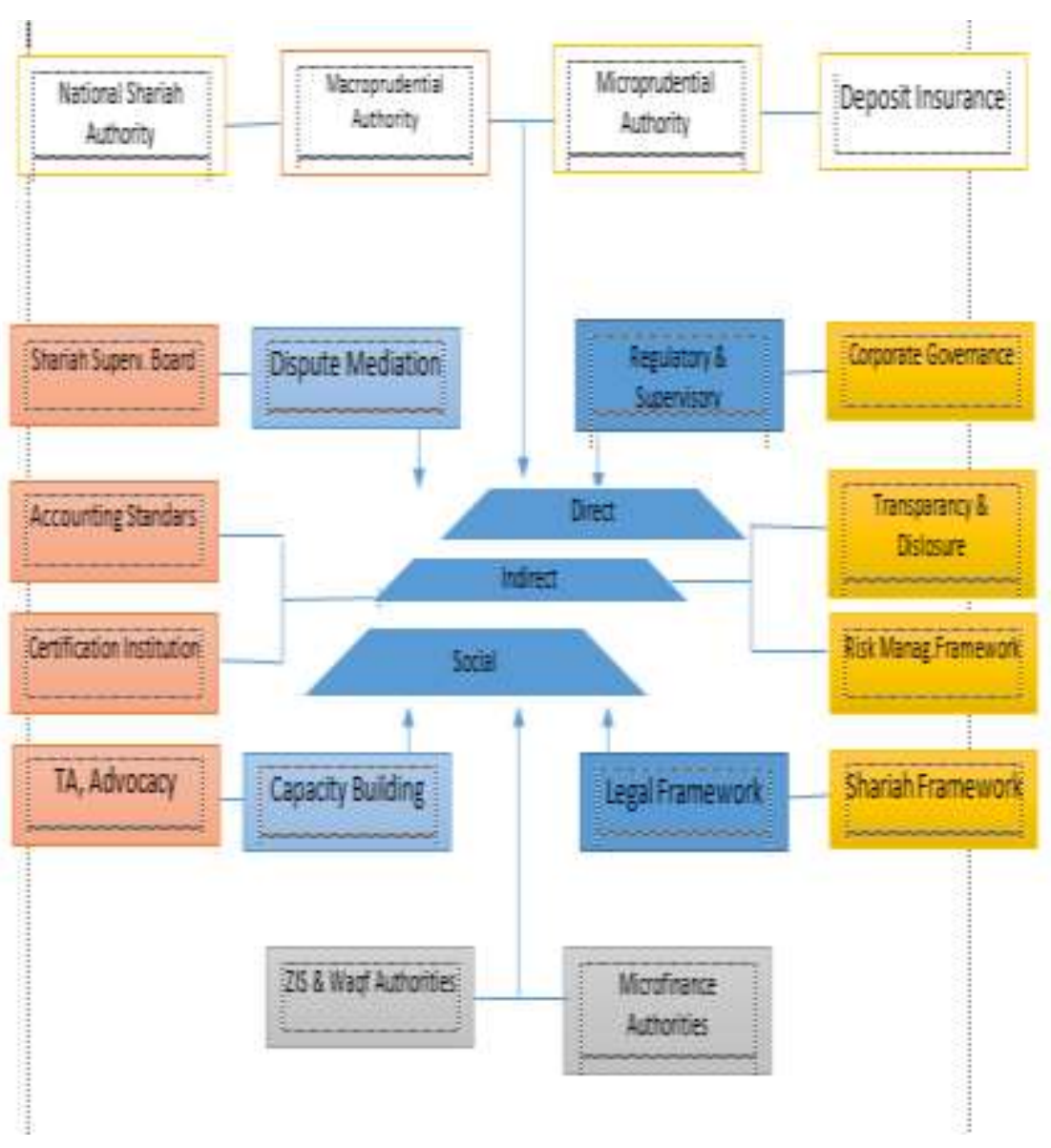

Figure 1. Maqasid al-Shari'ah Framwork in Developing Islamic Finance Product

Source : Laldin and Furqoni (2013) and Bank Indonesia 
All macro-Maqasid (ghoyah) can be achieved if micro-Maqasid (wasail) are correctly applied. Correct financial contract based on value and standard issued by the regulator, and the existence of social finance institutions are the three requirements in realizing all macro Maqasid. The combination of macro and micro Maqasid, at the certain level will promote the safeguarding of 5 human necessities namely faith, life, intellect, posterity, and wealth. In developing Islamic finance product, all above Maqasid must be the main framework in their mind. It is very important to ensure that the products issued are not only complying with sharia, but also Maqasid Ash-Shari'ah.

In the left-side of above picture explain the concept of Maqasid Ash-Shari'ah framework both macro-Maqasid and micro-Maqasid. Whereas, the right-side is the main important pre-requisite as the component in Isalmic financial infrastructure in realizing maslahah. In this regard, four main component is requied namely sharia authority, macroprudential authority, microprudential authority, and deposit insurance authority. Sharia authority will ensure that all practices of islamic finance comply to sharia and also in line with sharia vision in attaining publics interest. This role can be conducted by National Sharia Board and Sharia Supervisory Board. Macroprudential authority plays vital role in ensuring the resilience and the stability of the whole Islamic financial system. Bank Indonesia will take this task by doing Islamic monetary policy and payment system. In addition, microprudential will focus on the operational of Islamic financial institutions. Whereas, deposit insurance will increasse the confidence of customer to use islamic financial product. All this parts are very crucial in realizing the product of Islamic finance can contribute significantly to the Maqasid al-Shari'ah.

In technical point of view, developing Islamic finance product can use some legal maxims as technical guideline. The table below consists of some Islamic legal maxims and its aplication in Islamic finance product. Some Islamic legal maxims which have direct relationship to Maqasid al-Shari'ah are related to the intention of 
product development (legal maxim in table 1). This legal maxim says that 'matters are determined according to intention'. From this side, islamic finance product must be developed based on spirit of sharia. Hence, bai' al-inah is strictly prohibitted, since this type of sales is quite same as just for legal trick to avoid riba. The second maxim is principle of harm prevention together with the concept of maslahah has been a subject of wide discussion in the field of Islamic jurisprudence. A number of legal maxim related to the harm prevention as stated in the table 1 below.

Table 1. Legal Maxim, Maqasid al-Shari'ah and its Application ${ }^{5}$

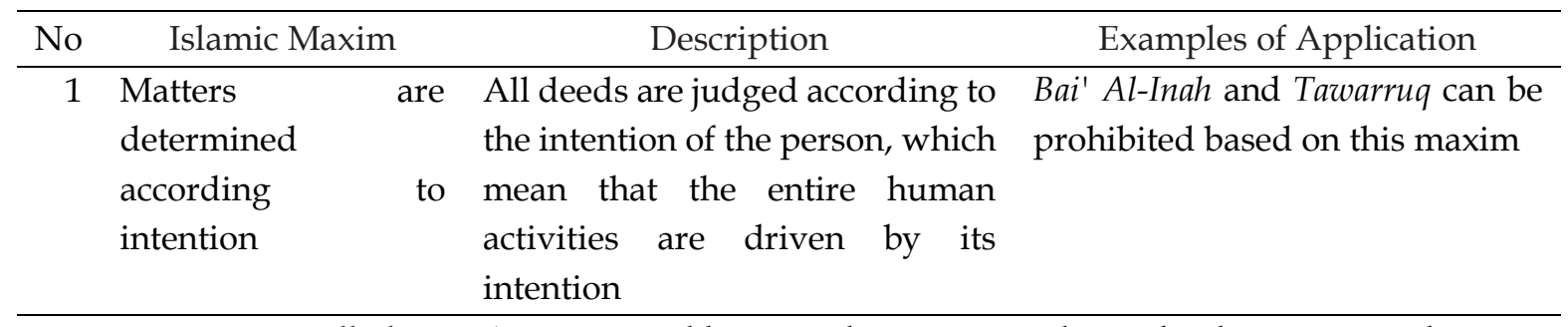

2 Harm is repelled as Any potential harm to the society far as possible. has to be prevented as much as possible. This resembles the proverb 'prevention is better than cure'. It is easier to prevent something from happening rather than treating it when it has already happened.
Islamic banks must not become involved in any activities that may in the long-run cause harm to society. For example, becoming involved in speculative trading activities which are not linked to the real economic activities such as the derivatives market.

If an Islamic bank identifies any sharia violation in its activities, immediate action must be taken to rectify the transaction. Corrective measures must be put in place to ensure such an event may not recur in future.

${ }^{5}$ This maxims are as described by Asyraf Wajdi Dusuki and Said Bouheraoua in their paper with the title The Framework of Maqasid Al-Sharī'ah and Its Implication for Islamic Finance, Islam and Civilisational Renewal", Pluto Jurnal. Pp. 331 
Volume 12(2), 2018

\begin{tabular}{|c|c|c|c|}
\hline No & Islamic Maxim & Description & Examples of Application \\
\hline 4 & $\begin{array}{l}\text { No injury to be } \\
\text { inflicted when lifting } \\
\text { an injury. }\end{array}$ & $\begin{array}{l}\text { In an attempt to remove harm or } \\
\text { damage, it must not invoke } \\
\text { another type of harm either in the } \\
\text { same degree of harm or worse. }\end{array}$ & $\begin{array}{l}\text { In managing risk banks must not } \\
\text { use conventional risk } \\
\text { management tools which can } \\
\text { invoke higher risk such as using } \\
\text { derivatives or securitization } \\
\text { techniques like Credit-Default } \\
\text { Swaps (CDS) and Mortgage- } \\
\text { Backed Securities (MBS), which } \\
\text { are proven to have detrimental } \\
\text { effects on society in the long-run. }\end{array}$ \\
\hline 5 & $\begin{array}{l}\text { Severe damage is } \\
\text { avoided by a lighter } \\
\text { damage. }\end{array}$ & $\begin{array}{l}\text { If harm or damage is } \\
\text { unavoidable, the strategy is to } \\
\text { choose a lighter damage. Another } \\
\text { similar maxim is that the smaller } \\
\text { of two harms is chosen. }\end{array}$ & $\begin{array}{l}\text { In the event where an Islamic } \\
\text { bank has no other option except } \\
\text { to use a controversial contract } \\
\text { like tawarruq in managing its } \\
\text { liquidity, it may do so because } \\
\text { the damage of a collapsed bank } \\
\text { due to liquidity crisis is more } \\
\text { severe and can be disastrous to } \\
\text { the whole financial system. }\end{array}$ \\
\hline 7 & $\begin{array}{l}\text { Harm must be } \\
\text { eliminated }\end{array}$ & $\begin{array}{l}\text { This maxim stated that any form } \\
\text { of harm that may afflict people in } \\
\text { one of essential aspect of their } \\
\text { lives must be eliminated }\end{array}$ & $\begin{array}{l}\text { Bank Indonesia must raise the } \\
\text { income qualification requirement } \\
\text { to the credit card applicant to } \\
\text { prevent the people for taking } \\
\text { more debt. }\end{array}$ \\
\hline 8 & $\begin{array}{l}\text { The repealing of } \\
\text { harm is preferred to } \\
\text { the attainment of } \\
\text { benefts. }\end{array}$ & $\begin{array}{l}\text { If there is a conflict between harm } \\
\text { and beneft, it is obligatory to } \\
\text { repeal or lift the harm first even if } \\
\text { by so doing it will remove the } \\
\text { benefits. This is because harm can } \\
\text { easily spread and cause severe } \\
\text { damage, and hence priority ought } \\
\text { to be given to the aversion of } \\
\text { harm over attaining benefits }\end{array}$ & $\begin{array}{l}\text { A debt-based instrument like } \\
\text { murabahah, given its legal and } \\
\text { valid contract from the sharia } \\
\text { viewpoint, its extensive use } \\
\text { accentuates inequality and } \\
\text { exposes one to a wide-array of } \\
\text { risk as it redistributes wealth in } \\
\text { favour of suppliers of capital, } \\
\text { irrespective of actual } \\
\text { productivity of the finance } \\
\text { supplied. Hence, it should be } \\
\text { minimized and eventually } \\
\text { averted. }\end{array}$ \\
\hline
\end{tabular}




\begin{tabular}{rlll}
\hline No & \multicolumn{1}{c}{ Islamic Maxim } & \multicolumn{1}{c}{ Description } & \multicolumn{1}{c}{ Examples of Application } \\
\hline 9 & $\begin{array}{l}\text { Hardship Begets } \\
\text { Facility }\end{array}$ & $\begin{array}{l}\text { This maxim denotes that Islam } \\
\text { has strong concern in relieving } \\
\text { hardship and difficulties and } \\
\text { promote ease. }\end{array}$ & $\begin{array}{l}\text { Actual cost determination for } \\
\text { each Islamic banking product is } \\
\text { very difficult Hence, Islamic } \\
\text { bank can use accumulation and } \\
\text { then distributed to all product. It } \\
\text { is based on the Fatwa of Islamic }\end{array}$ \\
& & & Fiqh Academy.
\end{tabular}

The other basic principles in Islamic legal maxim which has strong match with Maqasid al-Shari'ah is "hardship beget facility". In the context of the current application of Islamic finance whereby the culture and environtment is conventional worldview, this maxim is very essential. For example, in actual cost determination for each Islamic banking product is very difficult. Hence, Islamic bank can use accumulation and then distributed to all product. It is based on the fatwa of Islamic Fiqh Academy.

\section{Conclusion}

The most difficult problem in which be the main focus of Islamic finance expert is the issue of Maqasid al-Shari'ah. Therefore, it is very crucial to discuss on the framework of Maqasid al-Shari'ah both in macro level and micro level. This framework will imply that Islamic finance practices will be shaped by the higher objective of 
sharia, namely masalahah. Moreover, with the existance of this framework, performance of Islamic finance, especially its product can be easy traced.

It is intended to solve the problem of pseudo-islamic finance product which just mimicking its conventional counterparts. Nowadays, Islamic finance is much more than just refraining from charging interest and conforming to the legal technicalities and requirements on offering Islamic financial products. With respect to managing diverse expectations and interests, the sharia provides a framework for managers to resolve problems arising from the potential conflicting responsibilities towards the various stakeholders.

In particular, framework of Maqasid, which consist of macro and micro Maqasid will guide the high orientation of Islamic finance product. In addition, these two Maqasids will altogether realized the maslahah dhoruriyyat of human being, namely faith, life, intellect, posterity, and the wealth. In doing so, some basic authorities are needed in ensuring all functions of Maqasid are running well. For example, sharia authority, macroprudential authority, microprudential authority, and insurance authority.

In the case of product development in Islamic finance, some Islamic legal maxims must be injected as their basic foundation to create new Islamic product. Some of the basic legal maxims are, related to the important of intention, harm must be prevented, hardship begets facility, and the important rule of ummatic need. All of these principles are as a guiding principle in product development.

\section{References}

Ahmed, H. (2011). Product Development in Islamic Banks. Edinburgh: Edinburgh University Press Ltd.

Ahmed, H. (2011b). Maqasid al-Shari' ah and Islamic Financial Products: a Framework for Assessment. ISRA International Journal of Islamic Finance, Vol. 3 (1): 149-160.

Al-Ashqar, S. (2004). Al-Waadhih fi Usul al-Figh, Jordan: Dar al-Nafais. 
Al-Ghazali, M. (1998). Al-Mustasfa Min 'ilm Al-usul. Beirut: Dar al-Kutub alIslamiyyah.

Al-Mubarak, T. and Noor, M. O. Applications of Maqasid al-Shari'ah and Maslahah in Islamic Banking practices: An analysis. IIUM Textbook.

Al-Syatibi. (1991). Al-Muwafaqat fi Usul al-Syari'ah. Beirut: Dar al-Kutub al-Ilmiyyah Vol.2.

Antonio, M.S. et al. (2012). An Analysis of Islamic Banking Performance: Maqashid Index Implementation in Indonesia and Jordania. Journal of Islamic Finance, Vol. 1 (1): 012 - 029.

Asutay, M. (2012). Conceptualising and Locating the Social Failure of Islamic Finance: Aspirations of Islamic Moral Economy vs. the Realities of Islamic Finance. Asian and African Area Studies, Vol. 11(2): 93-113.

Asutay, M. and Astrid F.H. (2015). Developing Maqasid al-Shari'ah Index to Evaluate Social Performance of Islamic Banks: A Conceptual and Empirical Attempt. International Journal of Islamic Economics and Finance Studies, Vol. $1(1): 5$.

Auda, J. (2013). Maqasid a-Shariah as Philosophy of Islamic Law. London: IIIT.

Ayub, M. (2007). Understanding Islamic Finance. West Sussex, England: John Wiley \& Sons.

Chapra, M. U. (1998). Relevance and Importance of Islamic Economics. In M. Kahf (Ed.), Lessons in Islamic Economics, Vol. 1: 99-114. Seminar Proceedings No. 41. Jeddah: Islamic Research and Training Institute (IRTI).

Chapra, M. U. (2008). The Islamic Vision of Development in the Light of the Maqasid Ash-Shari'ah. Occasional papers series 15. London: The International Institute of Islamic Thought (IIIT).

Dusuki, A.W. and Said B. (2007). The Framework of Maqasid Al-Sharī'ah and Its Implication for Islamic Finance, Islam and Civilisational Renewal. Pluto Jurnal: 331.

Dusuki, A.W. (2009). Challenges of Realizing Maqasid al-Shari' ah (Objectives of Shari' ah) in Islamic Capital Market: Special Focus on Equity-Based Sukuk. International Islamic Management Conference on Islamic Capital Market, Organised by Centre for Islamic Management Studies University Sains Malaysia; 28th \& 29th October 2009, USM, Penang. Pp. 2. 
Elahi, Monzur-E-M. (2010). The Objectives and Intents of Islamic Shari ah as a Paradigm of Development Strategies and Policies. IIUC Studies, Vol. 7: 321336.

Hurayra, M.A. (2015). Achievement of Maqasid-al-Shari'ah in Islamic Banking: An Evaluation of Islamic Bank Bangladesh Limited. Global Journal of Computer Science and Technology: A Hardware \& Computation, Vol. 15 (1): 9.

Ibn Ashur, M. A.T. (2006). Treatise on Maqasid al-Shari'ah (M. E.-T. El-Mesawi, Trans.). Washington: The International Institute of Islamic Thought.

Ibn Qayyim, A.J. (n.d.). I'lām al-Muwaqqĩ'in (Vol. 3). Cairo: Idārah al-Tibā'ah alMunïriyyah.

Kamali, M.H. (2009). Maqasid al Shari'ah Made Simple. Occasional Papers Series 13. The International Institute of Islamic Thought, London \& Washington.

Khallaf, A.W. (1990). 'Ilm Usul al-Figh. Cairo: Maktabah al-Da'wah al-Islamiyyah: 84

Lahsasna, A. and Sulaiman, R. (2010). Realizing Maqasid al Shari'ah in Islamic Financial Planning. Paper presented at the 4th Islamic banking, accounting and finance seminar (IBAF 2010).

Lahsasna, A. (2013). Maqasid Ash-Shari'ah in Islamic Finance. Kuala Lumpur: IBFIM.

Laldin, M.A. et al. (2013). Islamic Legal Maxim and Their Aplication in Islamic Finance. Kuala Lumpur: ISRA.

Laldin, M.A. and Hafa, F. (2013). Developing Islamic finance in the framework of maqasid al-Shari' ah: Understanding the Ends (maqasid) and the Means (Wasa'il). International Journal of Islamic and Middle Eastern Finance and Management, Vol. 6 (4): 278-289.

Mohamad Y.I. et al. (2015). The Practices of Islamic Finance in Upholding the Islamic Values and the Maqasid Shari'ah. International Review of Management and Business Research, Vol. 4 (I): 286-294.

Mohammad, M. O. and Syahidawati S. (2013). The Objective of Islamic Economic and Islamic Banking in Light of Maqasid Al-Shari'ah: A Critical Review. Middle-East Journal of Scientific Research 13 (Research in Contemporary Islamic Finance and Wealth Management): 75-84. 